ISSN: $1412-8837$

\title{
AUDIT SUMBERDAYA MANUSIA: STUDI KASUS PADA BALAI PENELITIAN BIOTEKNOLOGI PERKEBUNAN INDONESIA
}

\author{
(Human Resources Audit: Case Study In Center For Indonesian \\ Plantation Biotechnology Research)
}

\author{
Reswita \\ Jurusan Sosial Ekonomi Pertanian \\ Fakultas Pertanian Universitas Bengkulu
}

\begin{abstract}
The aims of this study are to analyze human resources function in the employee' perpectives In Center for Indonesian Plantation Biotechnology Research (Balai Penelitian Bioteknologi Perkebunan Indonesia), identify the aspects which should be improved, and identify functions needed to manage intensively. Descriptive research method is used and non parametric statistics including range criteria test, cartesius diagram, and Whitney and Kruskall Wallis are applied to analyze data gathered from 59 respondent who are censused. The reserach concludes that human resource management has not been solidity. For the future, its implementation should be improved for human resources development in this research center.

Key words: audit human resources, responsibility, assessment system, development
\end{abstract}

\section{PENDAHULUAN}

\section{Latar Belakang}

Sumberdaya manusia merupakan faktor sentral dalam menentukan keberhasilan suatu organisasi. Apapun bentuk serta tujuannya, organisasi dibentuk berdasarkan visi untuk kepentingan manusia dan dalam pelaksanaan misinya dikelola dan diurus oleh manusia. Jadi, sumberdaya manusia merupakan faktor strategis dalam semua kegiatan institusi atau organisasi. Secara internal organisasi menghadapi masalah produktivitas, mutu, biaya, waktu, pelayanan, keselamatan, lingkungan dan prilaku pekerja. Sementara, secara eksternal, organisasi mendapat tekanan terus menerus dari berbagai penjuru antara lain dari konsumen pengguna jasa, lembaga swadaya masyarakat, pers dan pemerintah dengan berbagai macam perubahan yang tidak terduga. Untuk menghadapi kompleksitas dan intensitas 
tantangan yang semakin berat, organisasi dituntut berfikir kreatif untuk menemukan berbagai terobosan bagi pencapaian tujuan organisasi.

Sumberdaya manusia merupakan aset perusahan yang berperan dalam berbagai aktivitas, terutama dalam pencapaian tujuan organisasi. Menurut Susilo (2002) audit sumberdaya adalah pemeriksaan dan penilaian secara sistimatis, objektif dan terdokumentasi terhadap fungsi-fungsi organisasi yang terpengaruh oleh manajemen sumberdaya manusia dengan tujuan dipenuhinya azas kesesuaian, efektifitas dan efisiensi dalam pengelolaan sumberdaya manusia untuk mendukung tercapainya sasaran-sasaran fungsional maupun tujuan organisasi secara keseluruhan baik untuk jangka pendek, jangka menengah maupun jangka panjang.

Audit sumberdaya manusia adalah kegiatan pemeriksaan dan penilaian artinya audit adalah suatu proses mencari dan mengumpulkan data dan informasi faktual, signifikan dan relefan sampai pada tahap pengambilan keputusan yang didasarkan pada hasil verifikasi dan penilaian auditor. Auditor memerlukan data berupa fakta, yaitu realita atau keadaan yang sebenarnya yang ada atau dapat dibuktikan benar-benar ada atau terjadi. Data dan fakta yang signifikan adalah data dan fakta yang masih ada hubunganya dengan permasalahan sumberdaya manusia atau kepentingan perusahaan secara keseluruhan dan dapat menjelaskan masalah secara terarah dan mendalam. Audit sumberdaya manusia dilakukan seara sistematis, artinya proses pemeriksaan dan penilian dilakukan dengan pola logika dan menerapkan azas-azas manajemen. Audit sumberdaya manusia direncanakan, pelaksanaanya dikendalikan, dievaluasi dan hasilnya ditindak lanjuti

\section{Tujuan Penelitian}

Tujuan penelitian ini adalah mengkaji pengelolaan fungsi sumberdaya manusia di BPBPI ditinjau dari perspektif karyawan.

\section{METODE PENELITIAN}

\section{Lokasi dan Penelitian}

Penelitian ini dilakukan di Balai Penelitian Bioteknologi Perkebunan Indonesia yang berlokasi di Bogor.

\section{Jenis dan Sumber Data}

Dalam penilitian ini data yang dikumpulkan terdiri dari dua jenis yaitu data primer dan data skunder. 
ISSN: $1412-8837$

a. Data primer

Data yang yang diperoleh melalui wawacara langsung kepada responden dengan mengajukan beberapa pertanyaan yang tercantum dalam daftar pertanyaan (kuesioner), aitu mengenai :

Pertanyaan 1-10 mengenai pengetahuan sitem organisasi BPBPI

Pertanyaan 1-14 mengenai Iklim kerja di BPBPI

Pertanyaan 1-15 mengenai Efektifitas Manajemen SDM BPBPI

Pertanyaan 1-20 mengenai Implementasi Efektifitas Manajemen SDM BPBPI

Pertanyaan 1-10 mengenai Kompensasi SDM BPBPI

Pertanyaan 1-40 mengenai Peran dan Fungsi SDM

Jumlah responden yang diminta pendapatnya sebanyak 54 orang, yaitu karyawan tetap BPBPI yang terdiri dari 13 Sub uran, pengawas intern, dan satpam.

b. Data sekunder

Data skunder diperoleh melalui penelusuran hasil-hasil penelitian yang telah dilakukan peneliti lain, study pustaka dan dokumen kepegawaian yang berasal dari instansi yang berhubungan langsung dan relevan dengan penelitian.

\section{Analisis Data}

Teknik Rentangan Kriteria

Selanjutnya Umar (2004) mengemukakan ada beberapa tahapan yang diperlukan pada teknik rentang kriteria ini, yang dapat dijabarkan sebagai berikut : Pengelompokan Jawaban

Dari sejumlah kuesioner yang telah disebarkan pada responden diukur dengan skala Likert, yaitu skala ordinal yang pengukurannya memuat penyataan sikap seseorang terhadap sesuatu. Penelitian ini menggunakan 5 tingkat kesetujuan yang diajukan kepada responden, sebagai berikut:

Bobot 1 = sangat tidak setuju (STS)

Bobot 2 = tidak setuju (ST)

Bobot 3 = ragu-ragu $(\mathrm{R})$

Bobot 4 = setuju (S)

Bobot 5 = sangat setuju (SS)

Selanjutnya hasil jawaban responden dikelompokkan seperti diperlihatkan pada Tabel 1.

50 Reswita. Audit Sumberdaya Manusia (Studi Kasus pada Balai Penelitian Bioteknologi 
Tabel 1. Pengelompokan Jawaban

\begin{tabular}{|c|c|c|c|c|c|c|}
\hline \multirow{2}{*}{$\begin{array}{c}\text { Kriteria yang } \\
\text { Diteliti }\end{array}$} & \multicolumn{5}{|c|}{ Frekuensi Jawaban Tiap Kriteria } & \multirow{2}{*}{ Skor } \\
\hline & 1 & 2 & 3 & 4 & 5 & \\
\hline Kriteria 1 & $\mathrm{~N}_{1.1}$ & $\mathrm{~N}_{1.2}$ & $\mathrm{~N}_{1.3}$ & $\mathrm{~N}_{1.4}$ & $\mathrm{~N}_{1.5}$ & S1 \\
\hline Kriteria 2 & $\mathrm{~N}_{2.1}$ & $\mathrm{~N}_{2} .2$ & $\mathrm{~N}_{2.3}$ & $\mathrm{~N}_{2.4}$ & $\mathrm{~N}_{2}$ & S2 \\
\hline Kriteria 3 & $\mathrm{~N}_{3.1}$ & $\mathrm{~N}_{3} .2$ & $\mathrm{~N}_{3.3}$ & $\mathrm{~N}_{3.4}$ & $\mathrm{~N}_{3.5}$ & S3 \\
\hline Kriteria i & $\mathrm{Ni} .1$ & $\mathrm{Ni} .2$ & $\mathrm{Ni} .3$ & $\mathrm{Ni} .4$ & $\mathrm{Ni} .5$ & $\mathrm{Si}$ \\
\hline
\end{tabular}

Sumber: Umar (2004).

Untuk menghitung skor tiap komponen adalah dengan mengali seluruh frekuensi data dengan nilai bobotnya.

1. Menghitung Skor

Setelah jawaban dikelompokan kedalam tabel diatas, kemudian dihitung skor setiap elemen, yaitu dengan persamaan sebagai berikut:

$$
\begin{aligned}
& S i=\sum\left(b_{j} x n_{i j}\right) \\
& S_{\mathrm{i}}=\text { Skor baris } \\
& \mathrm{b}_{\mathrm{j}}=\text { Bobot pada kolom ke-j } \\
& \mathrm{n}_{\mathrm{ij}}=\text { Jumlah/frekuensi jawaban pada baris ke-I dan kolom ke-j }
\end{aligned}
$$

2. Menentukan Rentang Skala

Menentukan rentang skala merupakan langkah selanjutnya setelah skor masing-masing elemen diperoleh. Untuk menghitung rentang skala teersebut digunakan rumus sebagai berikut :

$$
R S=\frac{n(m-1)}{m}
$$

RS = Rentang Skala

$\mathrm{N}=$ Jumlah Contoh

$\mathrm{M}=$ Jumlah Alternatif Jawaban tiap Intem

3. Menentukan Skala Penilaian tiap Kriteria

Langkah selanjutnya adalah menentukan rentang skor terendah dan rentang skor tertinggi. Apapun rentang skor terendah yang diperoleh dari hasil perkalian antara jumlah sampel dengan bobot terendah, yaitu 1, dan adalah 
hasil yang diperoleh dari hasil perkalian antara jumlah sampel dengan bobot tertinggi, yaitu 5. Setelah ditentukan rentang terendah dan tertinggi, selanjutnya ditentukan interval skala penilian tiap kriteria seperti berikut:

Rtr $\quad-$ RS (+Rtr) $\rightarrow$ sangat lemah

Rtr (+1) - RS (+Rtr) $\rightarrow$ lemah

$\operatorname{Rtr}(+1)-R S(+R \operatorname{tr}) \rightarrow$ agak kuat

$\operatorname{Rtr}(+1)-$ RS (+Rtr) $\rightarrow$ kuat

Rtr $(+1)$ - Rtt $\rightarrow$ sangat kuat

\section{HASIL DAN PEMBAHASAN}

\section{Penilaian terhadap Sistem Organisasi}

Sistem organisasi yang terdiri dari pengetahuan terhadap organisasi umum yang menyangkut pengetahuan umum tentang visi misi BPBPI, nilai-nilai yang dibangun BPBPI atau budaya BPBPI, langkah-langkah manajemen yang ditempuh oleh BPBPI, tujuanBPBPI, dan rencana jangka panjang BPBPI dan pengetahuan terhadap unit kerja sendiri, yang meliputi rencana unit kerja, tujuan unit kerja, prosedur kerja dan tanggung jawab terhadap pekerjaan.

Sebanyak $44 \%$ responden menyatakan cukup tahu tentang sitem organisasi yang ada di BPBPI, sebanyak 29\% menyatakan kurang tahu, sebanyak 24\%) menyatakan tahu dan $2 \%$ yang menyatakan sangat kurang tahu dan sangat tahu.

Kurangnya pengetahuan responden terhadap sistem organisasi yang berlaku di BPBPI disebabkan karena kurangnya sosialisasi system organisasi oleh pihak manajemen. Sebagian karyawan merasa kurang dilibatkan dalam kegiatan rapat ataupun sosialisasi hasil rapat, terutama seperti apa sitem organisasi yang berlaku sekarang, misalnya visi, misi, kebijakan BPBPI, langkah-langkah manajemen yang ditempuh BPBPI dan rencana dan strategi perusahaan. Setiap tahun di BPBPI terus ada perubahan kebijakan-kebijakan dan strategi tetapi hal ini kurang disosialisasikan kepada karyawan.

Berdasarkan hasil perhitungan dengan analisis rentang kriteria, berkaitan dengan pengetahuan organisasi. Pengetahuan organisasi umum karyawan berada pada rentang cukup baik, aspek pertama visi misi dengan skor 166, aspek pertama visi misi dengan skor 166, nilai-nilai budaya yang dibangunBPBPI dengan skor 150,

52 Reswita. Audit Sumberdaya Manusia (Studi Kasus pada Balai Penelitian Bioteknologi 
kebijakan BPBPI denga skor 149, tujuan dan rencana jangkaa panjang dengan skor 146, dan langkah-langkah manajemen yang ditempuh BPBPI dengan skor 142. Pengetahuan tentang unit kerja berada pada rentang criteria cukup baik, aspek pertama tanggung jawab terhadap perkejaan dengan skor 183, prosedur kerja dengan skor 166, tujuan dan rencana kerja unit kerja masing-masing dengan skor 158.

Karyawan pada umumnya mengetahui sistem (rencana dan tujuan kerja) yang ada di unit kerja namun kurang mengetahui mengenai sistem organisasi secara umum. Ditinjau dari sistem organisasi, disetiap unit kerja, para karyawan telah memahami terhadap rencana kerja, tujuan unit yang akan dicapai serta prosedur kerja di masing-masing unit kerjanya. Akan tetapi pengetahuan sitem secara umum kurang dipahami oleh karyawan, seperti nilai-nilai yang dibangun BPBPI, langkah-langkah manajemen yang ditempuh BPBPI dan tujuan BPBPI. Oleh karena itu, perlu dilaksanakan sosialisasi yang lebih transparan mengenai sistem oleh pihak manajemen, denga harapan segenap karyawan BPBPI menjadi lebih memahami danlebih termotivasi untuk bersama-sama mengembangan BPBPI.

\section{Penilaian terhadap Iklim Kerja}

Penilaian terhadap iklim kerja karyawan menyangkut clarity (kejelasan), standar, responsibility (tanggung jawab), fleksibility (fleksibilitas), team commitment (komitmen tim kerja), dan reward (penghargaan). Sebanyak $62 \%$ menatakan raguragu dengan iklim kerja yang terjadi saat ini yang berlaku di BPBPI, diantaranya kejelasan, responsibility, fleksibility, dan team commitment dan sebanyak 38\% responden menyatakan tentang iklim kerja yang terjadi saat ini, yaitu reward dan standar. Dari hasil rentang kriteria diperoleh skor yang mencerminkan kondisi kerja sekarang di BPBPI.

Penilaian responden mengenai komitmen tim, yaitu mengenai hubungan kerja yang dibangun karyawan berada dalam kriteria setuju dengan skor 166, penilian responden mengenai standar, yaitu penilaian karyawan mengenai manajemen dalam memberikan penilaian terhadap hasil kerja serta dilakukan perbaikan-perbaikan berada dalam kriteria setuju dengan skor 183, penilain responden terhadap sistem penghargaan, yaitu penilaian karyawan mengenai perhatian dan penghargaan yang diberikan manajemen atas dasar pekerjaan yang dihasilkan berada dalam kriteria setuju dengan skor 216, penilaian responden 
ISSN: $1412-8837$

terhadap kejelasan, yaitu penilain karyawan mengenai arah dan tujuan organisasi, prosedur kerja dan kewenangan yang dijalankan dan diberlakukan oleh manajemen berada dalam kriteria yang disetujui oragu-ragu dengan skor 150, penilaian responden terhadap fleksibilitas, yaitu penilaian karyawan mengenai kemudahan mengemukakan gagasan-gagasan baru yang disetujui oleh BPBPI berada dalam kriteria ragu-ragu dengan skor 154, dan penilaian tanggung jawab responden, yaitu mengenai penilaian karyawan mengenai tingkat kebebasan untuk mengerjakan tugas-tugas yang menjadi tanggung jawabnya tanpa perlu untuk selalu dikontrol oleh atasannya dalam criteria cukup baik dengan skor 168 .

Dari hasil wawancara yang dilakukan, sebagian besar responden menyatakan ide-ide baru dan orosinil mereka dikelompok kerja sulit dan dipertimbangkan, tingkat kesetiaan dikelompok masih diragukan. Karyawan raguragu rekan-rekan di kelompok kerja bersedia keluar dari kebiasaan jelek demi kesuksesan kelompok kerja, saling bekerja sama satu dengan yang lain, dan rekanrekan di BPBPI dihargai atau hasil kerja yang baik. Karyawan merasakan masih marasa sulit untuk mengemukakan gagasan-gagasan dan merasa terlalu banyak dikontrol sehingga sulit untuk membuat keputusan.

\section{Penilaian terhadap Implementasi Iklim Kerja di BPBPI}

Implementasi manajemen sumberdaya manusia di BPBPI selama ini berada dalam kriteria kurang kurang dan cukup. Implementasi manajemen sumberdaya manusia yang kurang dirasakan responden dari BPBPI, indicator pertama adalah kebutuhan tenaga kerja setiap bagian dikomunikasikan dan dimintakan persetujuan atasan dengan skor 157. Selanjutnya, indikator struktur organisasi BPBPI menggambarkan secara jelas hirarki wewenang dan lingkup tanggung jawab setiap pimpinan unit dengan skor 153, program pemberian apresiasi/ penghargaan dengan sasaran yang jelas dilaksanakan secara periodic dan kontinyu serta melibatkan pimpinan puncak dengan skor 152, organisasi sumberdaya dibentuk sesuai dengan kebutuhan dan pertumbuhan perusahan dengan skor 149, fungsi sumberdaya manusia dijalankan secara sistematik dengan skor 146, perbaharuan data karyawan secara berkala dengan skor 144, dan sistem pelaporan pekerjaan secara terpola dn konsistem diseluruh jajaran karyawan/pimpinan dengan skor 142, tingkat produktifitas karyawan dipantau dan ditinjau secara berkala dan hasilnya digunakan untuk perencanaan pengembangan karyawan.

54 Reswita. Audit Sumberdaya Manusia (Studi Kasus pada Balai Penelitian Bioteknologi 
Faktor-faktor yang dirasakan cukup oleh responden adalah kebijakankebijakan sumberdaya manusia diputuskan sesuai kebutuhan perusahaan dan rencana pengembangan perusahaan dengan skor 172, BPBPI membangun sistem komonikasi antara karyawan dan pimpinan secara dua arah dengan skor 167, karyawan-karyawan yang profesional dan berkualitas tinggi dijaga dan dipertahankan dengan baik melalui sistem penggajian yang kompetitif dengan skor 161, target kerja ditentukan secara jelas dan spesifik serta melibatkan karyawan dalam menentukan batas waktu penyelesaian dan perioritas target dan BPBPI mempunyai peraturan-peraturan perusahaan dalam status yang masih berlaku dan terus diperbaharui secara berkala dengan skala dengan skor 154, karyawan menilai perusahaan secara positif ketika berada di luar perusahaan dengan skor 153, karyawn aktif dan bergairah dalam menjalankan tugas dan tanggung jawabnya dan senang terhadap iklim yang ada dan pengukuran tingkat kepuasan karyawan dilakukan secara berkala dan informasi mengenai tingkat kepuasan karyawan telah ada datanya dan dijadikan acuan dalam tindakan perbaikan dengan skor 151, dan stuktur gaji dan paket total imbal jasa yang disediakan oleh BPBPI tidak lebih rendah dibanding perusahaan sejenis dengan skor 147.

Dari hasil wawancara dengan responden kebutuhan kerja setiap bagian di BPBPI kurang dikomunikasikan dan dimintakan persetujuan atasan. Yang dirasakan responden selama ini adalah adanya kekurangan karyawan untuk membantu pelaksanaan tugas, khususnya tenaga teknisi dan peneliti. Struktur organisasi yang ada belum menjelaskan secara jelas garis hierarki wewenang dan tanggung jawab setiap pimpinan unit kerja. Lingkup wewenang, tugas, dan tanggung jawab belum ada yang brlaku, organisasi belum sepenuhnya dibentuk untuk sesuai dengan kebutuhan dan pertumbuhan perusahaan aakan tetapi masih untuk kepentingan pimpinan kerja, data-data karyawan jarang sekali diperbaharui, dan tidak pernah dilakukan pengukuran produktifitas.

\section{Penilaian terhadap Efektifitas Pengelolaan Manajemen SDM}

Efektifitas pengelolaan sumberdaya manusia selama ini berada dalam rentang kriteria kurang memuaskan dan cukup memuaskan. Pengelolaan sumberdaya yang kurang memuaskan dari BPBPI menurut responden, indikator adalah sistem penilaian kerja dengan skor138, selanjutnya penghargaan atas prestasi dengan skor 135, tunjangan dinas luas dan pengembangan karir 134, tunjangn dinas luar dengan 
ISSN: $1412-8837$

skor 132, sistem penggajian dan imbalan dengan skor 128, program pensiunan, pendidikan dan pelatihan dengan skor 125 . Sedangkan pengelolaan sumberdaya manusia yang dirasakan sudah memuaskan oleh responden, yang pertama adalah lingkungan kerja dengan skor 153, kejelasan tugas, tanggung jawab dan wewenang dengan skor 152, sistem dan prosedur kerja dan internalisasi mengenai kebanggaan akan perusahaan dengan skor 149, kegiatan social dengan skor 144, dan sarana kerja dan kesesuai antara pekerjaan denngan pemegang jabatan dengan skor 140.

Efektivitas manajemen sumberdaya manusia yang diingginkan oleh responden semua berada dalam posisi perlu pembenahan dan pembenahan seperlunya saja. Aspek-aspek yang memerlukan pembenahan menurut responden, yang pertama adalah internalisasi mengenai kebanggaan akan perusahaan dengan skor139, selanjutnya adalah sarana kerja, kejelasan tugas, wewenang dan tanggung jawab dengan skor 135, sistem dan prosedur kerja dengan skor 131, tunjangan dinas luar dengan skor 129, kesesuaian antara jabatan dan pemegang jabatan dengan skor 126, penghargaan atas prestasi dengan skor 125, pengembangan karir, pendidikan dan pelatihan dengan skor 123, sistem penggajian/imbalan jasa dan penilaian kerja dengan skor 122, tunjanggan kesejahteraan dengan skor 120, dan program pension dengan skor 111.

Hal ini mengindikasikan bahwa karyawan menginginkan adanya pembenahan-pembenahan untuk masa yang akan datang. Para karyawan berharap adanya langkah-langkah pengembangan yang berkesinambungan, misalnya dengan melakukakan pengukuran kepuasan karyawan. Hasil yang didapat dapat digunakan sebagai pedoman untuk perbaikan. Perlu ditinjau kembali mengenai halhal yang berkaitan dengan sistem tunjangan dan sistem penggajian. Para karyawan belum dapat penghargaan terhadap prestasi kerjanya, termasuk sistem pengembangan karir yang sedang berjalan. Karyawan memiliki tanggung jawab yang tinggi terhadap pekerjaan yang ditugaskan kepadanya. Para karyawan dapat melakukan kerjasama dan percaya terhadap rekan kerja, para karyawan selalu memberikan citra yang positif terhadap nama baik perusahaan sedangkan manajemen melakukan implementasi program peningkatan pelayanan kepada karyawan dengan tujuan untuk pengembangan diri.

56 Reswita. Audit Sumberdaya Manusia (Studi Kasus pada Balai Penelitian Bioteknologi 


\section{Penilaian Terhadap Komptensi Karyawan di Setiap Unit Kerja}

Kompetensi sumberdaya manusia dapat dinilai dari kerjasama dalam tim, dan bekerjasama ini merupakan aspek yang mendukung terhadap produktifitas kerja. Bertanggung jawab terhadap pekerjaan sebagai bentuk komitmen pribadi terhadap pekerjaan dengan memperlihatkan citra yang positif. Sedangkan aspek integritas profesional yang merupakan keterlibatan potensi yang menyeluruh, terlihat dengan jelas dilakukan karyawan.

Kompetensi karayawan di setiap unit BPBPI sudah baik, yaitu, saling bekerjasama dalan tim dengan skor 199, selanjutnya loyalitas terhadap BPBPIdengan skor 196, orientasi pada produktifitas kerja dengan skor 195, pengelolaan waktu dengan skor 192, dan tanggung jawab terhadap pekerjaan dengan skor 187. Sedangkan kompetensi kaeryawan yang berada dalam rentang cukup yaitu, orientasi pelayanan dengan skor 186, integritas personal dengan skor 185, kepekaan antar pribadi dengan skor 180, memotivasi orang lain dengan skor 172, dan penyelesaian masalah dengan skor 187.

Kemampuan perusahaan dalam mempertahankan karyawan merupakan konsep kualitatif yang mendukung berkembangnya kemampuan sumberdaya manusia. Perusahaan dapat mempertahankan karyawan yang berkinerja bagus dan memudahkan karyawan yang bekrkinerja biasa-biasa saja untuk memperbaiki diri sendiri. Disamping itu, untuk mempertahankan karyawan dapat dilakukan melalui reward, pengembangan latihan dan karir. Standar prilaku dari karyawan yang paling bagus kinerjanya dan mendukung strategi perusahaan menjadi dasar untuk kebijakan pengelolaan sumberdaya manusia, seperti rekrutmen, relaksasi, imbalan, manajemen kerja, promosi, dan pengembangan. Melalui cara ini berarti telah dikaitkan antara strategi dan manajemen simberdaya manusia dan strategi korporat. Strategi jangka panjang perusahaan mengenai sumberdaya manusia, didasari oleh pemikiran bahwa kemampuan perusahaan dan sumberdaya manusia memberikan arah dasar bagi strategi perusahaan. Kopetensi sumberdaya manusia yang terintegrasi dengan core competencies perusahaan merupakan sumber dari value perusahaan.

\section{Penilaian Terhadap Fungsi dan Peranan SDM dalam Organisasi}

Responden menyatakan bahwa kinerja suburusan cukup baik dan tidak berbeda dari divisi-divisi lainnya dengan jenis pekerjaan yang berbeda-beda, 
ISSN: $1412-8837$

namun peran SDM yang diketahui masih hanya sebatas sebagai Employee Champion sedangkan untuk peran lain yaitu: Change Agent Administration Expert, Strategic Partner masih kurang. Pada seluruh fungsi/jabatan perlu pengembangan dan pembinaan mengenai melakukan hubungan kerja/kepekaan antar pribadi.

\section{SIMPULAN DAN SARAN}

\section{Simpulan}

Dari hasil penelitian dapat ditarik kesimpulan pengelolan fungsi SDM di BPBPI belum optimal dan implementasi pada setiap fungsi SDM masih kurang

\section{Saran}

Perlu dilakukan sosialisasi mengenai sistem organisasi, pengelolaan iklim kerja, pengelolaan efektifitas manajeman dan implementasi lebih ditingkatkan dan dievaluasi.

\section{DAFTAR PUSTAKA}

Http://www.xeec.net/result/teori+sumber+daya+manusia.html. Diakses pada tanggal 5 januari 2005

Susilo, W. 2002. Audit SDM: Panduan Kompherensif auditor dan Praktisi Manajemen Sumberdaya Manusia serta Pimpinan Organisasi/Perusahan. PT. Vorgistatama Binamega. Jakarta

Umar, H. 2004. Evaluasi Kinerja Perusahaan. PT. Gramedia Pustaka Utama. Jakarta

58 Reswita. Audit Sumberdaya Manusia (Studi Kasus pada Balai Penelitian Bioteknologi 